удК 346.1

DOI https://doi.org/10.32837/apdp.v0i83.120

\title{
О.Р. Ковалишин
}

\section{КОРПОРАТИВНИЙ КОМПЛАСНС: ПРАВОВЕ ЗАПОЗИЧЕННЯ ЧЕРЕЗ ПРАКТИКИ СУБ'СКТІВ ГОСПОДАРЮВАННЯ}

Постановка проблеми. За даними Corruption Perceptions Index 2018, що щорічно публікується міжнародною організацією Transparency International, Україна посідає 120-те місце (32 бали зі 100 можливих) [1]. Таким чином, рівень відповідності антикорупційних практик підприємств України поки що не повністю відповідає міжнародним стандартам, тому набирає обертів застосування практик корпоративного комплаєнсу.

Термін «комплаєнс» (з англ. compliance) означає відповідність, згода від англійського слова “to comply", що перекладається як «відповідати». Комплаєнс увійшов у термінологічний обіг акціонерних правовідносин одночасно з приходом іноземних інвесторів, для яких дотримання корпоративного комплаєнсу є необхідною умовою стабільної діяльності компанії. Дотримання вимог корпоративного комплаєнсу на сьогодні є однією із мінімальних вимог для позиціонування компанії як такої, яка намагається відповідати міжнародним стандартам ведення господарської діяльності. Фактично можна вести мову про те, що корпоративний комплаєнс $€$ одним із принципів корпоративного управління. Між тим на рівні нормативного закріплення цей принцип корпоративного управління залишається практично неурегульованим.

Аналіз останніх досліджень і публікацій. Комплаєнс є переважно предметом дослідження науковців у сфері банківської справи та управління О. Ковальчука [2], О.М. Сарахмана [3], Л.А. Клюско [4], М.Е. Хуторна [5], І.В. Коляда [6] або ж 3 точки зору антикорупційного права (В.Ф. Оболонцев [7], Т.В. Момот [8]). Таким чином, термін комплаєнс не є новим для права України та практики застосування. Одночасно з тим нормативне розуміння корпоративного комплаєнсу відсутне, як відсутнє і відповідне наукове обгрунтування цього поняття у фаховій літературі.

Мета статті полягає в з'ясуванні змісту корпоративного комплаєнсу та передумов його виникнення.

Виклад основного матеріалу дослідження. Необхідність корпоративного комплаєнсу обумовлена тим, що: 1) практика корпоративного комплаєнсу уже стала частиною корпоративних стандартів компаній в країнах ЄС, США та інших. При цьому зміст такого корпоративного комплаєнсу полягає не лише дотриманні певних правил корпоративної поведінки в середині компанії. Стандартами корпоративного комплаєнсу диктується необхідність дотримання відповідних правил поведінки також з боку їх контрагентів. Усвідомлюючи цей факт, українські суб’єкти господарювання (в першу чергу ті, які націлені на встановлення і підтримку господарських відносин з іноземними партнерами) уже запроваджують відповідні практики корпоративного комплаєнсу в середині підприємства; 2) на етапі підготовки перед процедурами злиття та поглинання, створення спільних підприємств оцінка 
практики корпоративного комплаєнсу уже стала стандартною процедурою, оскільки дає можливість оцінити прозорість та добросовісність відповідного суб'єкта господарювання.

Інститут Corporate Compliance розвинувся в США і напряму пов'язаний із корпоративною відповідальністю. Один із перших прецедентів пов' язаний із покладенням відповідальності на компанію. Було розглянуто справу Dollar S.S.Co.v. United States, 1939, в якій апелянта було притягнуто до відповідальності за викидання сміття з корабля одним із членів екіпажу його судна в порту Гавайїв. Хоча апелянт і намагався довести, що вжив всіх заходів для попередження таки дій з боку працівника, а тому не відповідає за дії особи, які напряму не пов'язані з виконанням ним своїх обов'язків, суд не врахував ці аргументи [9, с. 117].

В іншій справі Hilton Hotels Corporation, 1972, суд відхилив аргументи захисту компанії, які базувалися на доктрині „ultra vires”. На компанію поклали відповідальність за дії їі менеджера з закупівель щодо незаконної відмови від підписання угоди. Суд зазначив, що наявність спеціальних внутрішніх положень та інструкцій, які забороняють працівникам вчинення відповідних дій, не може бути підставою для звільнення компанії від відповідальності [10 с. 118; 11].

Поштовхом для розвитку корпоративного комплаєнсу стали 60-70-ті роки XX століття, зокрема Вотергейтський скандал, коли було викрито численні випадки корупції, які стосувалися також приватних компаній. 3 метою протидії такій ситуації було прийнято Закон «Про корупцію за кордоном» (Foreign Corrupt Practices Act/FCPA), яким були встановлені жорсткі правила контролю, вимоги до бухгалтерської та фінансової документації, а також правила взаємовідносин 3 державними службовцями. Закон серед іншого зобов’язує компанії вести точний i деталізований облік правочинів та операцій з активами; розробляти і впроваджувати систему управлінського обліку і контролю; забезпечити здійснення правочинів із дозволу керівництва компанії.

У Сполученому Королівстві лише у 2010 р. після тривалих обговорень було прийнято Закон «Про боротьбу з хабарництвом» (UK Bribery Act). Відповідно до цього закону на компанії, що підпадають під його юрисдикцію, покладається обов’язок зі створення комплаєнс-служб [12, с. 108].

Корпоративний комплаєнс розглядається як один із засобів запобігання і протидії правопорушенням з боку посадових осіб. Як і в Україні, так і за кордоном суб’єкти господарювання несуть: 1) пряму відповідальність за правопорушення вчинені від імені товариства, 2) так і непряму: коли суб'єкт господарювання відповідає за вчинки посадових осіб суб'єкта господарювання, які хоча і були вчиненні не безпосередньо від їі імені, але в межах виконання посадових обов'язків цими особами. При цьому з точки зору дій компанії вона не вчинила нічого протиправного, але несе відповідальності за дії останніх. Такий вид відповідальності в країнах як континентального, так і прецедентного права має глибоке історичне коріння та випливає з доктрини respondeat superior ${ }^{1}$.

${ }^{1}$ Доктрина respondeat superior (з лат. «хай відповідає старший») - правова доктрина, згідно з якою принципал завжди відповідає за дії свого агента. 
Тому закріплення корпоративної відповідальності в юридичній літературі обгрунтовується двома основними причинами: 1) посадові особи суб'єкта господарювання діють в його інтересах, а звідси суб'єкт господарювання може отримати як вигоду так і збитки від таких дій; 2) оскільки посадові особи є найманими працівниками суб'єкта господарювання, останній має змогу контролювати їх дії. Відповідаючи за вчинки менеджменту, суб'єкт господарювання мотивований вживати відповідних заходів для забезпечення належної поведінки менеджменту з метою превенції правопорушень з їх боку [12, с. 108].

Корпоративний комплаєнс полягає у дотриманні певних стандартів і практик. Компанії усвідомлюють, що приділяючи роль дотриманню корпоративних стандартів (шляхом дотримання і виконання таких локальних актів, як Кодекс етики, Кодекс корпоративної поведінки тощо) вони тим самим знижують імовірність вчинення правопорушень з боку посадових осіб та працівників компанії.

Корпоративний комплаєнс в тому числі полягає у відповідності. Під відповідністю мається на увазі частина системи управління/контролю в організації, пов'язана з ризиками невідповідності, недотримання вимог законодавства, нормативних документів, правил і стандартів наглядових органів, галузевих асоціацій та саморегулюючих організацій, кодексів поведінки тощо. Такі ризики невідповідності в кінцевому підсумку можуть виявлятися у формі застосування юридичних санкцій або санкцій регулюючих органів, фінансових або репутаційних втрат.

Корпоративний комплаєнс є достатньо широким поняттям та не має чітких окреслених меж. Поряд із Кодексом корпоративної поведінки ним охоплюється політика, що регулює конфлікт інтересів завдяки впровадженню етичних стандартів поведінки співробітників у разі виникнення подібних конфліктів (інтереси посадової особи вступають у протиріччя з інтересами суб' єкта господарювання, інтересами одного з клієнтів тощо); політика інформування про порушення етичних стандартів (whistleblowing policy), що надає можливість працівникам як офіційно, так і анонімно повідомляти про випадки корупції та інших порушень норм і стандартів поведінки; політика чесної конкуренції, що вимагає від кожного співробітника виконання конкурентних правил та умов та направлена на формування вільного ринку та відкритої конкуренції товарів та послуг тощо.

Деякі елементи корпоративного комплаєнсу закріплені на законодавчому рівні. Зокрема, в Україні впроваджений інститут корпоративного секретаря, закріплено ряд норм щодо протидії корупції в товариствах капіталу (перш за все в акціонерних товариствах). Між тим, спеціального документу, який би прямо вказував на необхідність таких практик, немає. Наявні лише деякі галузеві нормативно-правові акти, які регулюють практику комплаєнсу в конкретних сферах.

У Методичних рекомендаціях щодо вдосконалення корпоративного управління в банках України № 98 від 28.03.2007 року (втратив чинність - прил. автора) містилася наступна дефініція: «комплаєнс - це діяльність пов'язана з дотриманням вимог законодавства та внутрішніх процедур» [13]. Комплаєнс у зазначеному вище документі передбачав необхідність знати, розуміти та дотримуватися всіх вимог законодавства України, нормативів, положень і правил, внутрішніх політик, стандартів та кодексів із питань діяльності банку. 
У чинних Методичних рекомендаціях щодо організації корпоративного управління в банках України № 814-рш від 03.12.2018 року [14] дефініція комплаєнсу відсутня. Але зазначається, що комплаєнс - це контроль за дотриманням норм (п. 80), який є частиною системи внутрішнього контролю як сукупності правил i заходів контролю організаційної та операційної структури банку, які включають поряд із комплаєнсом також процеси підготовки звітності і функції управління ризиками та внутрішній аудит (п. 1.2.9).

У Методичних рекомендаціях закріплена обов'язковість створення підрозділу комплаєнс, на який покладається відповідальність за здійснення контролю за впровадженням та дотриманням Кодексу поведінки (етики) та надання консультацій працівникам із питань дотримання кодексу поведінки (етики). Підрозділ комплаєнс не рідше одного разу на рік звітує раді банку про дотримання / недотримання кодексу поведінки (етики), про виявлені порушення та здійснені щодо їх недопущення в майбутньому заходи (ч. 4 п. 44).

Таким чином, на законодавчому рівні відсутні правові норми, які б прямо зобов'язували дотримуватися практик корпоративного комплаєнсу, що закономірно, оскільки за своєю правовою природою корпоративний комплаєнс є справою добровільною і рішення про його дотримання чи недотримання залежить виключно від волі управлінського органу товариства.

Корпоративний комплаєнс регулюється здебільшого на рівні локальних правових актів, таких як Кодекс корпоративної поведінки (Code of conduct), Кодекс корпоративної етики (Code of Ethics) тощо. Кодекс корпоративної поведінки є тим базовим локальним правовим актом, де містяться норми поведінки посадових осіб виконавчого та наглядового органів товариства, інших співробітників у взаємовідносинах між собою та з контрагентами, постачальниками та іншими третіми особами, з якими має справу та чи інша посадова особа (працівник) у процесі виконання своїх професійних обов'язків.

У судовій практиці комплаєнс тлумачиться в контексті дотримання норм фінансового законодавства, а судові рішення стосуються переважно притягнення до адміністративної відповідальності за його порушення.

Так, постановою по справі № 752/17033/17 відповідального працівника за проведення фінансового моніторингу - начальника Департаменту Комплаєнсу, члена Правління ПАТ «СІТІБАНК» було притягнуто до відповідальності та визнано винною у вчиненні правопорушення за ч. 1 ст. 166-9 КУпАП та застосувати адміністративне стягнення у видгляді штрафу в дохід держави в розмірі ста неоподатковуваних мінімумів доходів громадян, що становить 1700 (тисяча сімсот) гривень.

Особа_1, будучи відповідальним працівником за проведення фінансового моніторингу - начальником Департаменту Комплаєнсу, членом Правління ПАТ «CITIБАНК», направила файлом-повідомленням XА0IWI7P.703 інформацію про фінансові операції, які зареєстровані в реєстрі фінансових операцій 21.07.2017 року за № 25391-25404, лише 25.07.2017 року, тобто із запізненням на один робочий день.

Дослідивши матеріали справи, суд визнав за необхідне визнати Особа_1 винною за ч. 1 ст. 166-9 КУпАП, оскільки її вина підтверджується протоколом про адміністративне правопорушення та зібраними по справі матеріалами. 
Враховуючи характер вчиненого правопорушення, дані про особу, яка притягується до адміністративної відповідальності, наслідки вчиненого нею правопорушення та ступінь ї̈ вини, суд визнав за необхідне застосувати відносно неї адміністративне стягнення за ч. 1 ст. 166-9 КУпАП у видгляді штрафу [15].

Прецеденти, коли б учасники корпоративних правовідносин зверталися до суду за захистом прав у зв'язку з порушенням практик корпоративного комплаєнсу, майже відсутні, що зумовлено перш за все добровільним характером їх дотримання. Оскільки дотримання практик корпоративного комплаєнсу є справою добровільною, то й визнання відмінної поведінки посадових осіб товариства як протиправної є мало можливим.

Незначна поширеність корпоративного комплаєнсу в Україні зумовлена рядом факторів. По-перше, саме явище комплаєнсу в світі є досить новим. Як було зазначено вище, в більшості країн відповідне законодавство почало формуватись лише протягом останніх одного-двох десятиріч.

По-друге, важливим чинником впливу є особливості підприємницької культури в сфері господарювання. Україна - держава відносно молодої ринкової економіки. Для більшості суб'єктів господарювання несприйняття корупції все ще не є аксіомою поведінки, а стабільний довготривалий розвиток господарської діяльності не відноситься до їх стратегічних завдань. Не в останню чергу це зумовлено об'єктивними чинниками нестабільної економічної ситуації, пережитками пострадянської ідеології.

По-трете, однією з причин набуття поширеності практик корпоративного комплаєнсу в світі пов'язується часто з існуванням кримінальної відповідальності юридичних осіб за дії її посадових осіб. Саме наявність останньої була основною причиною розвитку відповідних практик в США та інших державах прецедентного права. Це поняття охоплюється поняттям Corporate liability, яке не слід сплутувати 3 корпоративною соціальною відповідальністю(Corporate social responsibility). Перше охоплює кримінальну відповідальність за дії менеджменту компанії, в той час як друге - корпоративна соціальна відповідальність - є відображенням ставлення компанії до свого продукту або послуги, до споживачів, працівників, партнерів у сфері здійснення господарської діяльності та полягає в гармонійному співіснуванні, взаємодії та постійному діалозі із суспільством, участі у вирішенні найгостріших соціальних проблем.

Точного аналогу Corporate liability в Україні немає, оскільки за законодавством України юридична особа не є суб'єктом злочину. Хоча тенденції руху у відповідному напрямі все ж мають місце $[16 ; 17 ; 18 ; 19]$. Схожий за своєю суттю інститут був запозичений на підставі Закону України «Про внесення змін до деяких законодавчих актів України щодо виконання Плану дій щодо лібералізації Європейським Союзом візового режиму для України стосовно відповідальності юридичних осіб» № 314-VII від 23 травня 2013 року [20].

До суб'єкта господарювання можуть бути застосовані лише заходи кримінально-правового характеру у випадку вчинення таких злочинів як легалізація (відмивання) доходів, одержаних злочинним шляхом; використання коштів, здобутих від незаконного обігу наркотичних засобів, психотропних речовин, їх аналогів, 
прекурсорів, отруйних чи сильнодіючих речовин, отруйних або сильнодіючих лікарських засобів; підкуп службової особи юридичної особи приватного права, незалежно від організаційно-правової форми; підкуп особи, яка надає публічні послуги, пропозиція, обіцянка або надання неправомірної вигоди службовій особі, зловживання впливом (ст.ст. 96-3 - 96-11 КК України). Загалом існує незначний відсоток кримінальних проваджень щодо притягнення юридичних осіб до кримінальної відповідальності, а рішення, якими покладено кримінальну відповідальність на юридичну особі, взагалі відсутні [21].

Висновки. 1. Корпоративний комплаєнс - це діяльність, пов'язана з контролем за дотриманням посадовими особами та працівниками вимог законодавства та локальних актів нормативного та ненормативного характеру в господарських товариствах.

2. Запозичення практик корпоративного комплаєнсу ще не набуло широкої популярності серед суб'єктів господарювання, що зумовлено низкою факторів: 1) новизною явища корпоративного комплаєнсу для бізнес-середовища не тільки України, але й в загальносвітовому масштабі; 2) особливостями ділової культури - іноді власникам суб'єкта господарювання простіше ліквідувати підприємство, репутація якого зазнала шкоди через протиправні дії менеджменту, ніж дбати систематично про дотримання посадовими особами корпоративного комплаєнсу; 3) обмеженістю кримінальної відповідальності юридичних осіб за законодавством України.

\section{Jimepamypa}

1. Corruption Perceptions Index, Transparency International / URL: https://www.transparency.org/ cpi2018.

2. Ковальчук О. Поняття системи комплаєнс-контроль та особливості управління ризиком комплаєнс у банках України. Молодь і ринок. 2010. № 7-8. С. 153-157.

3. Сарахман О.М. Функціонування комплаєнс-контролю у вітчизняній банківській справі. Соціально-еконолічні проблеми сучасного періоду України. 2015. Вип. 2. С. 87-90.

4. Клюско Л.А. Фінансовий моніторинг та комплаєнс-контроль в банках. Финансы, учет, банки. 2014. Вып. 1. С. 153-160.

5. Хуторна М.Е. Організація ефективної системи комплаєнс-контролю в банку. Фінансовий простір. 2015. № 2. С. 112-118.

6. Коляда І.В. Поняття та сутність комплаєнс-контролю у вітчизняній економічній науці та суспільному дискурсі. Молодий вчений. 2016. № 12.1. С. 791-794.

7. Оболенцев В.Ф. Системний підхід у антикорупційному комплаєнсі. Проблеми законності. 2016. Вип. 134. С. 112-118.

8. Момот Т.В. Антикорупційний комплаєнс у системі стратегічного моніторингу кадрової безпеки підприємства. Актуальні проблеми еконоліки. 2016. № 6. С. 167-174.

9. Dollar S.S. Co.v. United States 101F.2d 638 (9th Cir. 1939). in Sharon Oded, Corporate Compliance: New Approaches to Regulatory Enforcement, 2013, p. 320

10. Hilton Hotels Corporation, 467 F. 2d 1000, (9th Cir. 1972), in Sharon Oded, Corporate Compliance: New Approaches to Regulatory Enforcement, 2013, p. 320.

11. Сидоренко Д., Комплаєнс: why do we need it? / Юридична газета, 15 травня 2018, № 19-20 (621-622) / URL: http://yur-gazeta.com/publications/practice/inshe/komplaens-why-do-weneed-it.html.

12. Sharon Oded, Corporate Compliance: New Approaches to Regulatory Enforcement, 2013, p. 320.

13. Про схвалення Методичних рекомендацій щодо вдосконалення корпоративного правління в банках України : Постанова правління Національного Банку України № 98 від 28.03.2007 року / URL: https://zakon.rada.gov.ua/laws/show/v0098500-07.

14. Про схвалення Методичних рекомендацій щодо організації корпоративного управління в банках України : Рішення Правління Національного банку України № 814-рш 03.12.2018 року / URL: https://zakon.rada.gov.ua/laws/show/vr814500-18. 
15. Постанова у справі № 752/17033/17 від 08.09.2017 року / URL: http://reyestr.court.gov.ua/ Review/68936545.

16. Цимбалюк В.І. Переваги та недоліки впровадження кримінальної відповідальності юридичних осіб у законодавство України. Актуальні проблеми політики. 2014. Вип. 53. С. 325-331.

17. Ковальова С.С. До питання про введення в Україні кримінальної відповідальності юридичних осіб. Науковий вісник Національного університету біоресурсів і природокористування України. Серія: Право. 2015. Вип. 213 (1). С. 225-232.

18. Абакумова Ю.В. Кримінальна відповідальність юридичних осіб: порівняльна характеристика. Право та державне управління. 2016. № 1. С. 32-41.

19. Гаврилішин А.П., Козирєва В.П. Проблеми кримінальної відповідальності юридичних осіб. Юридичний вісник. Повітряне і космічне право. 2018. № 2. С. 160-165.

20. Про внесення змін до деяких законодавчих актів України щодо виконання Плану дій щодо лібералізації Європейським Союзом візового режиму для України стосовно відповідальності юридичних осіб : Закон України № 314-VII від 23 травня 2013 року. Відомості Верховної Ради. 2014. № 12. ст. 18.

21. Трут Д., Автух А. Притягнення юросіб до кримінальної відповідальності в Україні: міф чи реальність? Юридична газета-оnline, 15 лютого 2016 / URL: http://yur-gazeta.com/publications/practice/ kriminalne-pravo-ta-proces/prityagnennya-yurosib-do-kriminalnoyi-vidpovidalnosti-v-ukrayini-mif-chirealnist.html.

\begin{abstract}
Анотація
Ковалишин О. Р. Корпоративний комплаєнс: правове запозичення через практики суб’єктів господарювання. - Стаття.

Дотримання вимог корпоративного комплаєнсу (corporate compliance) на сьогодні є однією із мінімальних вимог для позиціонування компанії як такої, яка намагається відповідати міжнародним стандартам ведення господарської діяльності. Фактично можна вести мову про те, що корпоративний комплаєнс є одним із принципів корпоративного управління.

Автор зазначає, що корпоративний комплаєнс - це діяльність, пов'язана з контролем за дотриманням посадовими особами та працівниками вимог законодавства та локальних актів нормативного та ненормативного характеру в господарських товариствах.

Корпоративний комплаєнс полягає у дотриманні певних стандартів і практик та у відповідності. Під відповідністю мається на увазі частина системи управління/контролю в організації, пов'язана з ризиками невідповідності, недотримання вимог законодавства, нормативних документів, правил i стандартів наглядових органів, галузевих асоціацій та саморегулюючих організацій, кодексів поведінки тощо. Такі ризики невідповідності в кінцевому підсумку можуть виявлятися у формі застосування юридичних санкцій або санкцій регулюючих органів, фінансових або репутаційних втрат.

У статті аргументується, що поняття корпоративного комплаєнсу неодмінно пов'язане з поняттям Corporate liability, яке не слід сплутувати з корпоративною соціальною відповідальністю (Corporate social responsibility).

У статті акцентується увага на тому, що запозичення практик корпоративного комплаєнсу не набуло ще широкої популярності серед суб'єктів господарювання, що зумовлено рядом факторів: 1) новизною явища корпоративного комплаєнсу для бізнес-середовища не тільки України, але й в загальносвітовому масштабі; 2) особливостями ділової культури - іноді власникам суб'єкта господарювання - простіше ліквідувати підприємство, репутація якого зазнала шкоди через протиправні дії менеджменту, ніж дбати систематично про дотримання посадовими особами корпоративного комплаєнсу; 3) відсутністю кримінальної відповідальності юридичних осіб за законодавством України, оскільки на нормативному рівні закріплені лише заходи кримінально-правового характеру.

Ключові слова: комплаєнс, корпоративний комплаєнс, правове запозичення, правовий трансплантат, кримінальна відповідальність юридичної особи, суб'єкт господарювання.
\end{abstract}




\section{Summary}

Kovalyshyn O. R. Corporate compliance: legal transplant through the companies best practices. Article.

Corporate compliance is currently one of the minimum requirements for positioning a company as one that seeks to meet international business standards. In fact, it can be said that corporate compliance is one of the principles of corporate governance.

The author points out that corporate compliance is an activity related to the control of compliance by law enforcement officials and employees with local regulations and regulations in companies.

The origin of corporate compliance is considered in the article. The author makes a conclusion that the concept of corporate compliance appeared after the financial scandal with Maxwell Corporation. The answer of the British government was the Cadbury Act that settled the base for the future corporate compliance in the british companies as well as all over the world.

Corporate compliance is about congruence with the certain standards and practices. Compliance refers to the part of the organization's management / control system related to the risks of non-compliance, non-compliance with the requirements of legislation, regulations, rules and standards of supervisory authorities, codes of conduct, etc. Such risks of non-compliance may ultimately be in the form of the application of legal or regulatory sanctions, financial or reputational losses.

The article argues that the concept of corporate compliance is inevitably linked to the concept of Corporate Responsibility, which should not be confused with Corporate social responsibility.

The article emphasizes that such legal transplant as corporate compliance practices has not gained wide popularity among business entities, due to a number of factors: 1) the novelty of corporate compliance for the business environment not only in Ukraine but globally; 2) business culture features - sometimes it is easier for business owners to liquidate an enterprise whose reputation has been damaged through unlawful management actions than to systematically observe corporate compliance by officials; 3 ) restrictions of criminal liability of legal entities under the legislation of Ukraine (legal entity isn't a subject of criminal liability in Ukraine but can be punished).

Key words: compliance, corporate compliance, legal borrowing, legal transplant, criminal liability of a legal entity, company. 